\section{Morphophysiological Traits and Nitrate Content of Greenhouse Lettuce as Affected by Irrigation with Saline Water}

\author{
Ida Di Mola and Youssef Rouphael ${ }^{1}$ \\ Department of Agricultural Sciences, University of Naples Federico II, \\ Portici 80055, Italy
}

\section{Giuseppe Colla}

Department of Agricultural and Forestry Sciences, University of Tuscia, Viterbo 01100, Italy

\section{Massimo Fagnano, Roberta Paradiso, and Mauro Mori \\ Department of Agricultural Sciences, University of Naples Federico II, Portici 80055, Italy}

Additional index words. Antioxidant activity, gas exchange, Lactuca sativa, nitrates, salt stress, stomatal limitation

\begin{abstract}
In a 2-year study, the morphophysiological and qualitative changes imposed to greenhouse lettuce (Lactuca sativa $\mathrm{L}$.) by an increasing concentration of $\mathrm{NaCl}$ in the irrigation water were determined. Plants were grown under soil conditions and supplied with irrigation water having electrical conductivities (ECs) of 0.7 (control), 0.9, 1.8, 3.6, or $7.2 \mathrm{dS} \cdot \mathrm{m}^{-1}$. Irrigation with saline water resulted in linear decrease in plant growth parameters (i.e., leaf number, total leaf area and head diameter), head fresh weight, and diameter as well as yield, especially at $1.8,3.6$, and $7.2 \mathrm{dS} \cdot \mathrm{m}^{-1}$, confirming that lettuce is a salt-sensitive crop. The percentage of marketable yield reduction in comparison with nonsaline control treatment was $22.7 \%, 36.4 \%, 45.4 \%$, and $63.6 \%$ at $0.9,1.8,3.6$, and 7.2 $\mathrm{dS} \cdot \mathrm{m}^{-1}$, respectively. The reduction in marketable fresh yield has been partly compensated by a decrease in the nitrate content of salt-treated lettuce. The highest values of hydrophilic antioxidant activity were recorded in the nonsalinized treatment. The lowest values of lipophylic antioxidant activity (LAA) and total ascorbic acid were observed under severe stress conditions $\left(7.2 \mathrm{dS} \cdot \mathrm{m}^{-1}\right)$. $\mathrm{Net} \mathrm{CO}_{2}$ assimilation rate and leaf water potential (LWP) declined with increasing $\mathrm{NaCl}$ concentration in the irrigation water. Increasing salinity in the irrigation water induced a reduction in stomatal conductance $\left(g_{\mathrm{s}}\right)$ as LWP dropped below $-0.62 \mathrm{MPa}$.
\end{abstract}

Salinity has been identified as a major abiotic stressor, decreasing yield worldwide (Rouphael et al., 2016). About 400 million hectares of agricultural lands all over the globe have been affected by salinity (FAO, 2014). Moreover, based on the global climate changes, salinization is expected to have an increased negative impact, posing a major threat to crop productivity in the years to come (Munns, 2002).

Excessive concentration of sodium chloride $(\mathrm{NaCl})$ in soil and water induces osmotic (i.e., water stress) and ionic (i.e., $\mathrm{Na}^{+}$and $\mathrm{Cl}^{-}$) stresses, leading to several physiological, anatomical, molecular, and metabolic changes (Munns, 2005; Ntatsi et al., 2017). Several greenhouse studies carried out on vegetable species demonstrated that salinity stress retards growth thereby reducing fresh and dry biomass accumulation (Colla et al., 2013b;

Received for publication 12 Sept. 2017. Accepted for publication 18 Oct. 2017.

${ }^{1}$ Corresponding author. E-mail: youssef.rouphael@ unina.it.
Lettuce (Lactuca sativa L.) is a major salad crop from the Astercaceae family, which is widely grown and consumed in Italy and in several other European countries (Rouphael et al., 2017c). It has garnered a crucial role in the human diet as it combines generally pleasing organoleptic properties with a rich content of bioactive compounds (minerals, vitamins, phenolic acids, and flavonoids; Kim et al., 2016b). On the other hand, lettuce plants are noted for their high nitrate accumulation, leading to a high intake of nitrate in the human diet (Amr and Hadidi, 2001). Nitrate per se is not toxic; however, its reaction metabolites (i.e., nitrite and nitric oxide) could have detrimental effects on human health in some target population groups (vegetarians, infants, and the elderly) with a higher probability of developing cancer (EFSA, 2008). Therefore, the European Commission regulation No. 1881/2006 established a safe threshold for nitrates in lettuce [3000-5000 mg. $\mathrm{kg}^{-1}$ fresh weight (FW)].

Most of the leafy vegetable crops including lettuce are salt-sensitive species which grow poorly in salinized soils (Mass and Hoffman, 1977). In the scientific literature, the agronomical, physiological, and structural responses of lettuce were investigated only at low $\left(0.9-1.5 \mathrm{dS} \cdot \mathrm{m}^{-1}\right)$ or very high $\left(>15 \mathrm{dS} \cdot \mathrm{m}^{-1}\right)$ saline conditions (Garrido et al., 2014; Kim et al., 2016a; Mahmoudi et al., 2011), whereas no published data are available concerning the effects of moderate salt stress $\left(1.8-7.2 \mathrm{dS} \cdot \mathrm{m}^{-1}\right)$ typical of coastal areas where leafy vegetables are grown under protected cultivation.

The aim of this 2-year study was to evaluate the effects of different concentrations of saline water on growth, yield, leaf gas exchange and water potential, antioxidant activity, ascorbic acid, and nitrate content of lettuce grown under greenhouse conditions.

\section{Materials and Methods}

Mori et al., 2008, 2011), induces impairment of membrane integrity (Colla et al., 2013a), hampers the nutrient uptake and translocation (Grattan and Grieve, 1999), reduces chlorophyll synthesis (Lucini et al., 2015; Rouphael et al., 2017b), and limits the photosynthetic $\mathrm{CO}_{2}$ fixation (Rouphael et al., 2017a). Moreover, anatomical changes in vegetable leaves such as increase in palisade, spongy parenchyma thickness, and the volume of intercellular spaces were also observed under saline conditions (Rouphael et al., 2017a). Although saline water generally reduces crop productivity, in many cases it can enhance nutritive quality as demonstrated with several vegetable crops grown under greenhouse conditions (Colla et al., 2006a, 2006b, 2006c, 2008, 2012; Rouphael et al., 2006, 2012 c). However, the quality response of vegetables to salinity may change in relation to several interacting parameters such as the growing environment, species or cultivars as well as the salt concentration, source, and the time of exposure of the stress (Rouphael et al., 2012a, 2017a).
Growth conditions, plant material, and experimental design. Two experiments were conducted in two different years (Expts. 1 and 2) in a polyethylene shelter situated at the experimental station of the University of Naples "Federico II" located in Portici (Naples), south Italy (lat. $40^{\circ} 49^{\prime} \mathrm{N}$; long. $14^{\circ} 20^{\prime} \mathrm{E}$ ). In both growing seasons, Lactuca sativa L. cv. Cambria (Vilmorin, Paris, France) was used.

A completely randomized block design with three replicates was used to compare five $\mathrm{NaCl}$ concentrations in the irrigation water having the following electrical conductivities $\left(\mathrm{EC}_{\mathrm{w}}\right): 0.7$ (nonsalinized control), $0.9,1.8,3.6$, or $7.2 \mathrm{dS} \cdot \mathrm{m}^{-1}$. Lettuce were transplanted at the two true-leaf stage on 10 Nov. (Expt. 1) and 7 Dec. (Expt. 2) at a plant density of 8 plants $/ \mathrm{m}^{2}$ in lysimeters of reinforced fiber glass with a diameter of $70 \mathrm{~cm}$ and a depth of $65 \mathrm{~cm}$. A layer of coarse sand and gravel, $10-\mathrm{cm}$ thick, was overlain by a repacked soil profile of $50 \mathrm{~cm}$. At the bottom of the lysimeter, a pipe serving as a drainage outlet connected the lysimeter to 
a drainage reservoir. The lysimeters were filled with a loamy sandy soil $(83 \%$ sand, $12 \%$ silt, and $5 \%$ clay), with a $\mathrm{pH}$ of 7.5 , EC of $0.9 \mathrm{dS} \cdot \mathrm{m}^{-1}$, organic matter of $0.72 \%(\mathrm{w} / \mathrm{w})$, total $\mathrm{N}$ at $0.56 \%$, available $\mathrm{P}$ at $6.7 \mathrm{mg} \cdot \mathrm{kg}^{-1}$, and exchangeable $\mathrm{K}$ at $107 \mathrm{mg} \cdot \mathrm{kg}^{-1}$. In both growing years, preplant fertilizers were broadcast $\left(\mathrm{kg} \cdot \mathrm{ha}^{-1} ; 130 \mathrm{P}_{2} \mathrm{O}_{5}\right.$ and $\left.150 \mathrm{~K}_{2} \mathrm{O}\right)$ and incorporated into the soil. Additional topdressing fertilizer $\left(100 \mathrm{~kg} \cdot \mathrm{ha}^{-1} \mathrm{~N}\right)$ was applied three times (at transplanting, 35 and $60 \mathrm{~d}$ after planting) at equal rates using $\mathrm{NH}_{4}$ $\mathrm{NO}_{3}$ as a source of $\mathrm{N}$. All plots were irrigated at $100 \%$ irrigation level based on the Hargreaves formula. Weeds were controlled with hand hoeing, and no pesticide applications were required to control pathogens and pests.

Crop growth and yield measurements. In both experiments, the number of leaves per plant, total leaf area, and specific leaf weight were measured during three phenological growing stages (rosette, early-heading, and midheading), whereas the head diameter and fresh weight were recorded four times during the growing cycles at the following phenological stages: rosette, early-heading, midheading, and mature head (i.e., harvest) (Subbarao, 1998). The leaf area was measured with an electronic area meter (Delta-T Devices Ltd., Cambridge, UK). The specific leaf weight was calculated as the ratio of leaf dry weight per unit area and expressed as $\mathrm{mg} \cdot \mathrm{cm}^{-2}$.

In both experiments, lettuce plants were harvested on $5 \mathrm{Feb}$. (Expt. 1) and 9 Mar. (Expt. 2) and the marketable yields were determined on all plants per experimental unit.

Analysis of nitrate, total ascorbic acid content, and hydrophilic and lipophylic antioxidant activities. Nitrate nitrogen $(\mathrm{N}$ $\mathrm{NO}_{3}$ ) content was determined during both growing cycles and at the four phenological growing stages (rosette, early-heading, midheading, and mature head) on water extract of the dried leaf samples $(0.5 \mathrm{~g})$ based on cadmium reduction method proposed by Sah (1994). The absorbance of the solution was determined at $550 \mathrm{~nm}$ wavelength, using a spectrophotometer Hach DR 2000 (Hach Co., Loveland, $\mathrm{CO}$ ), and the final result was expressed as $\mathrm{mg} \cdot \mathrm{kg}^{-1} \mathrm{FW}$ on the basis of the original sample dry matter content.

For Expt. 2 only, total ascorbic acid, defined as ascorbic acid (ASA) and dehydroascorbic acid (DHA), was assessed by spectrophotometric detection on fresh plant tissues as described by Kampfenkel et al. (1995). The absorbance of the solution was measured at $525 \mathrm{~nm}$, and the data were expressed as $\mathrm{mg}$ ascorbic acid on $100 \mathrm{~g}^{-1}$ fresh weight.

For Expt. 2 only, the hydrophilic fraction (HAA) from freeze-dried leaves $(0.2 \mathrm{~g})$ was extracted with distilled water and its antioxidant activity was measured with the N,N-dimethylp-phenylenediamine method (Fogliano et al., 1999). The lipophilic fraction (LAA) was also extracted from freeze-dried leaves $(0.2 \mathrm{~g})$ with methanol, and antioxidant activity of this extract was measured with the 2,2'-azinobis 3-ethylbenzothiazoline-6-sulfonic acid method (Pellegrini et al., 1999). The HAA and LAA were determined by ultraviolet-visible spectrophotometry. The absorbance of the solutions was measured at 505 and $734 \mathrm{~nm}$, respectively. HAA and LAA were expressed as mmol ascorbic acid (AA) and as mmol of Trolox (6hydroxy-2,5,7,8-tetramethylchroman-2-carboxylic acid) per $100 \mathrm{~g}$ of dry weight, respectively (Fogliano et al., 1999).

Leaf gas exchange and midday leaf potential. For Expt. 2 only, measurements of gas exchange were performed 50 days after transplanting, on fully expanded leaves (excluding the most external leaf layer), on two leaves per plant, in three plants per treatment. The leaf gas exchange measurements were carried out within $2 \mathrm{~h}$ across solar noon (i.e., between 1100 and $1300 \mathrm{HR}$ ). The net $\mathrm{CO}_{2}$ assimilation rate (A), $g_{\mathrm{s}}$, and transpiration rate (E) were measured with a portable infra-red gas analyzer WALZ HCM 1000 (Walz, Effeltrich, Germany). During the measurements, temperature inside the leaf chamber was $13.2 \pm$ $1.5^{\circ} \mathrm{C}$ (mean \pm standard deviation), and the light intensity recorded at the leaf level was $586.0 \pm 64.5 \mu \mathrm{mol} \cdot \mathrm{m}^{-2} \cdot \mathrm{s}^{-1}$ (mean \pm standard deviation). Instantaneous and intrinsic water use efficiency $\left(\mathrm{WUE}_{\mathrm{i}}\right.$ and $\mathrm{WUE}_{\text {int }}$ ) were calculated as $\mathrm{A} / \mathrm{E}$ and $\mathrm{A} / g_{\mathrm{s}}$, respectively.

At the same date, LWP $\left(\Psi_{1}\right)$ at midday (1200 HR local time) was measured using the pressure chamber (model 3005; Soil Moisture Equipment Corp., Santa Barbara, CA) technique (Scholander et al., 1965) and taking the precautions proposed by Turner and Long (1980).

Statistical analysis. Analysis of variance (ANOVA) of the experimental data was performed using the SPSS software package (SPSS 13 for Windows, 2001). Combined ANOVA over two growing seasons was performed for crop growth parameters, marketable yield, and nitrate content. In both years, orthogonal contrasts were used to compare concentration of saline water effects (Gomez and Gomez, 1983) on selected crop parameters.

\section{Results}

\section{Plant growth, marketable yield, and nitrate content}

In both years, the leaf number and leaf area decreased linearly in response to an increase in water salinity at the three phenological stages (Table 1). Moreover, except for the second phenological stage (i.e., earlyheading), the lettuce head characteristics (head diameter and head fresh weight) were significantly affected by both growing years and salinity treatments (Table 2). The decrease in the head fresh weight was much more pronounced at midheading and maturehead stages (Table 2). In fact, the percentage of the head fresh weight reduction at midheading stage in comparison with nonsaline control was $14.9 \%, 21.4 \%, 35.4 \%$, and $48.4 \%$ at $0.9,1.8,3.6$, and $7.2 \mathrm{dS} \cdot \mathrm{m}^{-1}$, respectively (Table 2 ).

Similarly to leaf and head characteristics, the nitrate content decreased linearly during the four phenological stages with the increase in water salinity from 0.7 to $7.2 \mathrm{dS} \cdot \mathrm{m}^{-1}$, with the lowest values recorded under severe salt stress conditions at early-mid-heading as well as at mature head (Table 2). Finally, irrespective of water salinity treatments, the leaf number, leaf area, head diameter and fresh weight, and nitrate content were significantly higher in the first year in comparison with the second year, whereas an opposite trend was observed for the specific leaf weight (Tables 1 and 2).

Table 1. Mean effects of growing year and irrigation with saline water on leaf characteristics of lettuce plants at three phenological growing stages.

\begin{tabular}{|c|c|c|c|c|c|c|c|c|c|}
\hline \multirow[b]{2}{*}{ Treatment } & \multicolumn{3}{|c|}{ Leaf number (no./plant) } & \multicolumn{3}{|c|}{ Leaf area $\left(\mathrm{cm}^{2} /\right.$ plant $)$} & \multicolumn{3}{|c|}{ Specific leaf weight $\left(\mathrm{mg} \mathrm{DW} / \mathrm{cm}^{2}\right)$} \\
\hline & Rosette & Early-heading & Mid-heading & Rosette & Early-heading & Mid-heading & Rosette & Early-heading & Mid-heading \\
\hline \multicolumn{10}{|l|}{ Year } \\
\hline Year 1 & $13.8 \mathrm{a}$ & $28.2 \mathrm{a}$ & $34.3 \mathrm{a}$ & $572.5 \mathrm{a}$ & $916.6 \mathrm{a}$ & $1,532.4 \mathrm{a}$ & $2.7 \mathrm{~b}$ & $3.3 \mathrm{~b}$ & $5.1 \mathrm{~b}$ \\
\hline Year 2 & $11.7 \mathrm{~b}$ & $24.3 \mathrm{~b}$ & $27.3 \mathrm{~b}$ & $146.1 \mathrm{~b}$ & $512.7 \mathrm{~b}$ & $775.6 \mathrm{~b}$ & $5.9 \mathrm{a}$ & $5.1 \mathrm{a}$ & $6.2 \mathrm{a}$ \\
\hline \multicolumn{10}{|l|}{$\mathrm{EC}\left(\mathrm{dS} \cdot \mathrm{m}^{-1}\right)$} \\
\hline 0.7 & $14.6 \mathrm{a}$ & $25.5 \mathrm{~b}$ & $33.6 \mathrm{a}$ & $444.0 \mathrm{a}$ & $788.9 \mathrm{a}$ & $1,436.5 \mathrm{a}$ & 4.1 & $3.8 \mathrm{~b}$ & 5.5 \\
\hline 0.9 & $12.8 \mathrm{~b}$ & $29.3 \mathrm{a}$ & $31.8 \mathrm{a}$ & $371.8 \mathrm{~b}$ & $777.2 \mathrm{ab}$ & $1,232.8 \mathrm{~b}$ & 4.2 & $4.2 \mathrm{a}$ & 5.7 \\
\hline 1.8 & $13.1 \mathrm{~b}$ & $26.3 \mathrm{ab}$ & $31.8 \mathrm{a}$ & $371.7 \mathrm{~b}$ & $769.2 \mathrm{ab}$ & $1,169.0 \mathrm{~b}$ & 4.3 & $4.1 \mathrm{ab}$ & 5.6 \\
\hline 3.6 & $11.3 \mathrm{c}$ & $24.1 \mathrm{~b}$ & $27.8 \mathrm{~b}$ & $312.1 \mathrm{c}$ & $640.6 \mathrm{bc}$ & $1,055.3 \mathrm{bc}$ & 4.5 & $4.4 \mathrm{a}$ & 5.6 \\
\hline 7.2 & $12.1 \mathrm{bc}$ & $25.9 \mathrm{ab}$ & $28.9 \mathrm{~b}$ & $297.2 \mathrm{c}$ & $597.5 \mathrm{c}$ & $876.4 \mathrm{c}$ & 4.5 & $4.4 \mathrm{a}$ & 5.7 \\
\hline \multicolumn{10}{|l|}{ Significance $^{z}$} \\
\hline Year (Y) & $* * *$ & $* *$ & $* * *$ & $* * *$ & $* * *$ & $* * *$ & $* * *$ & $* * *$ & $* * *$ \\
\hline Salinity (S) & L*** & $\mathrm{L}^{*}$ & L*** & $\mathrm{L} * * *$ & $\mathrm{~L}^{*}$ & $\mathrm{~L} * * *$ & NS & $\mathrm{L}^{* *}$ & NS \\
\hline $\mathrm{Y} \times \mathrm{S}$ & NS & NS & NS & NS & NS & NS & NS & $*$ & NS \\
\hline
\end{tabular}

${ }_{\mathrm{z}} \mathrm{L}=$ linear; NS, ${ }^{*}, * *, * * *$ Nonsignificant or significant at $P \leq 0.05,0.01$, or 0.001 , respectively. 


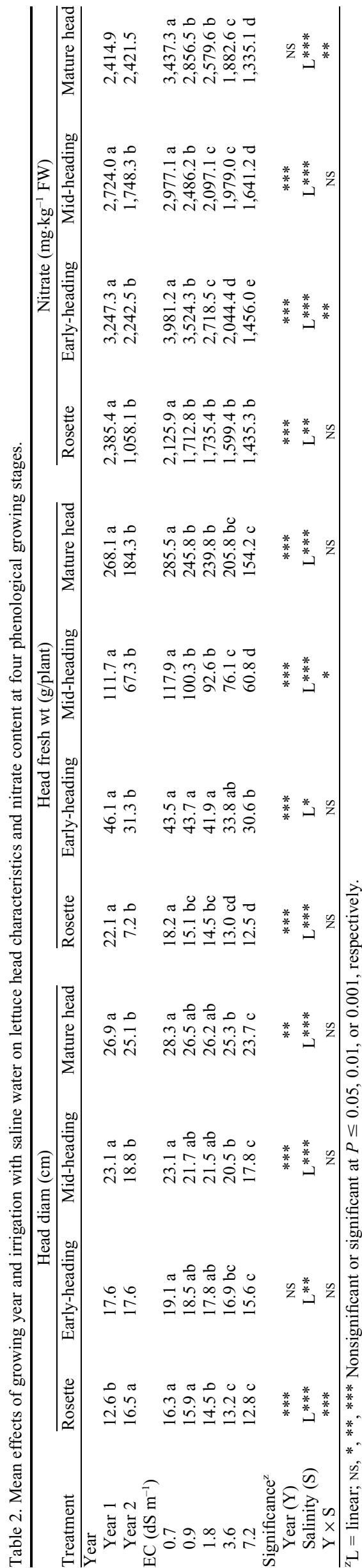

When averaged over water salinity treatments, the highest marketable yield was recorded during the first experiment compared with the second (Fig. 1). Moreover, irrespective of the growing year, increasing the EC of the irrigation water from 0.7 to 7.2 $\mathrm{dS} \cdot \mathrm{m}^{-1}$ decreased the marketable yield linearly. The percentage of marketable yield reduction in comparison with nonsaline control treatment was $22.7 \%, 36.4 \%, 45.4 \%$, and $63.6 \%$ at $0.9,1.8,3.6$, and $7.2 \mathrm{dS} \cdot \mathrm{m}^{-1}$, respectively (Fig. 1).

\section{Antioxidant activity and vitamin $C$ contents}

In Expt. 2, the HAA, LAA, and AA ranged from 10.9 to $12.6 \mathrm{mmol}$ ascorbic acid/100 g dry weight (DW) and from 21.0 to $26.3 \mathrm{mmol}$ Trolox/100 $\mathrm{g} \mathrm{DW}$ and from 10.9 to $11.3 \mathrm{mg} / 100 \mathrm{~g} \mathrm{FW}$, respectively (Table 3). The highest values of HAA were recorded in the nonsalinized treatment, whereas the lowest values of LAA and AA were observed under severe salt stress conditions (7.2 $\mathrm{dS} \cdot \mathrm{m}^{-1}$; Table 3$)$.

Leaf gas exchange and water potential. In Expt. 2, the net $\mathrm{CO}_{2}$ assimilation, $g_{\mathrm{s}}$, E, and midday leaf potential decreased linearly as the $\mathrm{EC}$ of the irrigation water increased from 0.7 to $7.2 \mathrm{dS} \cdot \mathrm{m}^{-1}$, whereas an opposite trend was recorded for the $\mathrm{WUE}_{\mathrm{i}}$ (Table 4). The lowest values of net $\mathrm{CO}_{2}$ assimilation, $g_{\mathrm{s}}$, and $\mathrm{E}$ were recorded with the 3.6 and $7.2 \mathrm{dS} \cdot \mathrm{m}^{-1}$ treatments, whereas no significant difference in comparison with the control was observed between the 0.9 and $1.8 \mathrm{dS} \cdot \mathrm{m}^{-1}$ treatments. Finally, the lowest and highest $\mathrm{WUE}_{\mathrm{i}}$ values were observed with the 1.8 and $3.6 \mathrm{dS} \cdot \mathrm{m}^{-1}$ treatments, respectively (Table 4).

\section{Discussion}

The inhibition of the photosynthesizing leaf area, stunted growth, and yield reduction are general responses of vegetables to excessive $\mathrm{NaCl}$ in irrigation water; and the decreasing in crop productivity may change in relation to several factors such as species/ cultivars, cultural environment, $\mathrm{NaCl}$ concentration, as well as the time of exposure to salt stress conditions (Munns, 2002). In the current experiment, irrigation with saline water had negative effect on plant growth parameters (i.e., leaf number, total leaf area, and head diameter) as well as on head fresh weight, especially at $1.8,3.6$, and $7.2 \mathrm{dS} \cdot \mathrm{m}^{-1}$, confirming that lettuce is a salt-sensitive crop (Lucini et al., 2015; Rouphael et al., 2016). Furthermore, the marketable yield reduction was much more pronounced under salt stress conditions ranging from $23 \%$ to $64 \%$ (at 0.9 and $7.2 \mathrm{dS} \cdot \mathrm{m}^{-1}$, respectively). Reduced shoot fresh weight of lettuce plants under saline treatments could be associated with $\mathrm{NaCl}$ increasing $\psi_{\mathrm{S}}$ (osmotic stress) and to salt-specific effects (ionic stress) inside the plant because of excessive $\mathrm{Na}^{+}$and $\mathrm{Cl}^{-}$uptake, leading to nutritional disorders and to the production of extreme ratios of $\mathrm{Na}^{+} / \mathrm{K}^{+}, \mathrm{Na}^{+} / \mathrm{Ca}^{2+}$, and $\mathrm{Cl}^{-} / \mathrm{NO}_{3}{ }^{-}$(Grattan and Grieve, 1999; Munns, 2005).
The significant depression in plant growth parameters and yield with increasing salinity has been demonstrated in other greenhouse experiments on tomato (Savvas et al., 2011), cucumber (Rouphael et al., 2012c), mini-watermelon (Colla et al., 2006b), melon (Colla et al., 2006c), pepper (Colla et al., 2006a), zucchini squash (Colla et al., 2008) as well as lettuce (Kim et al., 2016a; Lucini et al., 2015). In the present study, the marketable lettuce fresh yield started to decline at $0.7 \mathrm{dS} \cdot \mathrm{m}^{-1}$. Our findings are in agreement with those of Mass and Grattan (1999) and Kim et al. (2016a). By contrast, other authors have reported that the threshold for salinity tolerance of lettuce ranged between 1.1 and $2.0 \mathrm{dS} \cdot \mathrm{m}^{-1}$ (Andriolo et al., 2005; Unlükara et al., 2008). Explanations of this disagreement could be the different environmental conditions in which the plants were grown, and variations between lettuce groups or varieties (Mahmoudi et al., 2011). For instance, Pasternak et al. (1986) demonstrated that Butterhead and Crisphead lettuce types are generally less salt tolerant than Cos (i.e., Romaine) types.

It is generally accepted that moderate salinity reduces the vegetable productivity, but in many cases, improves the composition and concentration of phytochemicals (Colla et al., 2013a; Rouphael et al., 2006, 2012a, $2012 b)$. In fact, plants exposed to abiotic stress (i.e., salinity) will activate several physiological mechanisms to adapt to the suboptimal environment. Among these mechanisms, the synthesis of secondary metabolites (i.e., ascorbate and carotenoids) able to ensure plant growth even under harsh conditions (Kyriacou and Rouphael, 2017; Orsini et al., 2016). Interestingly, these secondary metabolites are considered an added value to basic nutritional characteristics of vegetables because of their health-promoting effects (Colonna et al., 2016). This was not the case in the present study as no significant differences between the non-salt control and the saline treatments (up to $3.6 \mathrm{dS} \cdot \mathrm{m}^{-1}$ ) were recorded for the LAA and total ascorbic acid contents, whereas a significant decrease in these quality parameters was observed under severe salt stress treatment (i.e., $7.2 \mathrm{dS} \cdot \mathrm{m}^{-1}$ ). The lowest content of total ascorbic acid observed at $7.2 \mathrm{dS} \cdot \mathrm{m}^{-1}$ could be attributed to the fact that under high $\mathrm{NaCl}$ concentration, the antioxidant system did not efficiently support reactive oxygen species scavenging in relation to salinity, as demonstrated by the sharp decrease in photosynthesis activity, plant growth, and marketable fresh yield.

It is also interesting to note that significant reduction in the accumulation of undesired compounds such as nitrate, most notably present in leafy vegetables, could be feasible under salt stress conditions (Kyriacou and Rouphael, 2017). In the present study, the percentage of nitrate content reduction at harvest (i.e., mature head) in comparison with nonsaline control was $16.9 \%, 24.9 \%$, $45.2 \%$, and $61.1 \%$ at $0.9,1.8,3.6$, and 7.2 $\mathrm{dS} \cdot \mathrm{m}^{-1}$, respectively. Moreover the nitrate content found were below the maximum limit of $4000 \mathrm{mg} \cdot \mathrm{kg}^{-1} \mathrm{FW}$ imposed by the European 


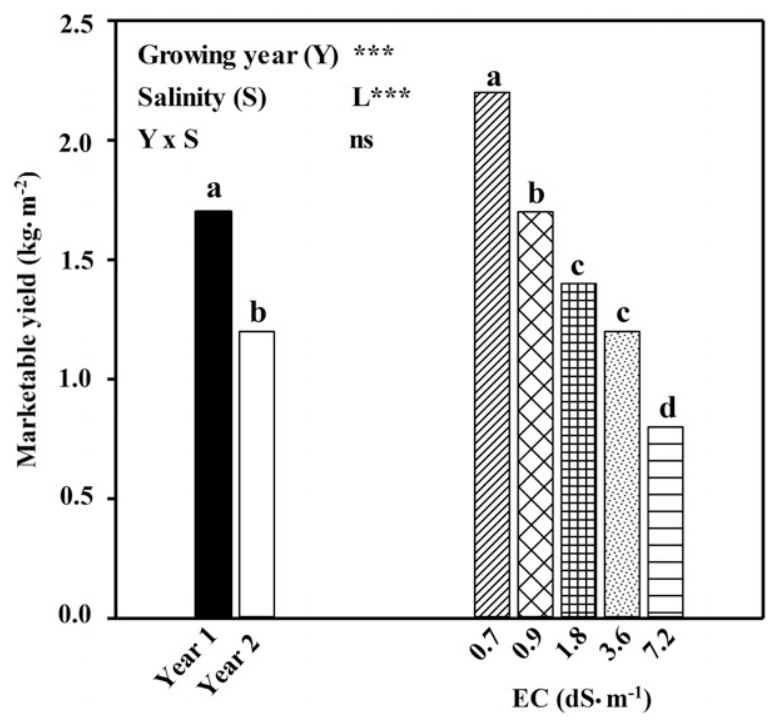

Fig. 1. Mean effects of growing year and irrigation with saline water on marketable yield of lettuce plants. Different letters indicate significant differences according to Duncan's test $(P<0.05)$.

Table 3. Effect of irrigation with saline water on hydrophilic and lypohilic antioxidant activities and total ascorbic acid of lettuce plants grown in the second growing year.

\begin{tabular}{lccc}
\hline & $\begin{array}{c}\text { Hydrophilic } \\
\text { antioxidant activity }\end{array}$ & $\begin{array}{c}\text { Lipophylic antioxidant } \\
\text { activity }(\text { mol } \\
\text { Trolox } / 100 \mathrm{~g} \mathrm{DW})\end{array}$ & $\begin{array}{c}\text { Total ascorbic } \\
\text { acid }(\mathrm{mg} / 100 \mathrm{~g} \mathrm{FW})\end{array}$ \\
$\mathrm{EC}_{\mathrm{w}}\left(\mathrm{dS} \cdot \mathrm{m}^{-1}\right)$ & $\begin{array}{c}\text { (mmol ascorbic acid } / 100 \mathrm{~g} \mathrm{DW}) \\
0.7\end{array}$ & $26.3 \mathrm{a}$ & $11.3 \mathrm{a}$ \\
0.9 & $12.6 \mathrm{a}$ & $21.6 \mathrm{a}$ & $11.3 \mathrm{a}$ \\
1.8 & $11.8 \mathrm{~b}$ & $21.3 \mathrm{a}$ & $11.3 \mathrm{a}$ \\
3.6 & $11.4 \mathrm{~b}$ & $20.8 \mathrm{a}$ & $11.3 \mathrm{a}$ \\
7.2 & $11.5 \mathrm{~b}$ & $21.0 \mathrm{~b}$ & $10.9 \mathrm{~b}$ \\
Significance $^{\mathrm{z}}$ & $10.9 \mathrm{~b}$ & $\mathrm{~L}^{*}$ & $\mathrm{~L}^{* *}$ \\
\hline
\end{tabular}

${ }_{\mathrm{z}}^{\mathrm{L}}=$ linear; NS, ${ }^{*}, * *$ Nonsignificant or significant at $P \leq 0.05$ or 0.01 , respectively.

Table 4. Effect of irrigation with saline water on net $\mathrm{CO}_{2}$ assimilation rate (A), stomatal conductance to water vapour $\left(g_{\mathrm{s}}\right)$, transpiration rate $(\mathrm{E})$, instantaneous water use efficiency $\left(\mathrm{WUE}_{\mathrm{i}}\right)$ and leaf water potential at midday $\left(\Psi_{1}\right)$ of lettuce plants grown in the second growing year.

\begin{tabular}{lccccc}
\hline & $\begin{array}{c}\mathrm{A}(\mu \mathrm{mol} \\
\left.\mathrm{CO}_{2} / \mathrm{m}^{2} / \mathrm{s}\right)\end{array}$ & $\begin{array}{c}g_{\mathrm{s}}(\mathrm{mmol} \\
\left.\mathrm{H}_{2} \mathrm{O} / \mathrm{m}^{2} / \mathrm{s}\right)\end{array}$ & $\begin{array}{c}\mathrm{E}(\mathrm{mmol} \\
\left.\mathrm{H}_{2} \mathrm{O} / \mathrm{m}^{2} / \mathrm{s}\right)\end{array}$ & $\begin{array}{c}\mathrm{WUE}_{\mathrm{i}}\left(\mu \mathrm{mmol} \mathrm{CO}_{2} /\right. \\
\left.\mathrm{mmol} \mathrm{H}_{2} \mathrm{O}\right)\end{array}$ & $\Psi_{1}(\mathrm{MPa})$ \\
\hline 0.7 & $7.1 \mathrm{a}$ & $60.1 \mathrm{a}$ & $1.0 \mathrm{a}$ & $8.0 \mathrm{ab}$ & $-0.24 \mathrm{c}$ \\
0.9 & $7.5 \mathrm{a}$ & $60.2 \mathrm{a}$ & $1.1 \mathrm{a}$ & $7.3 \mathrm{ab}$ & $-0.50 \mathrm{bc}$ \\
1.8 & $7.1 \mathrm{a}$ & $60.5 \mathrm{a}$ & $1.1 \mathrm{a}$ & $6.6 \mathrm{~b}$ & $-0.62 \mathrm{~b}$ \\
3.6 & $5.7 \mathrm{ab}$ & $46.9 \mathrm{~b}$ & $0.5 \mathrm{~b}$ & $10.6 \mathrm{a}$ & $-0.71 \mathrm{ab}$ \\
7.2 & $4.4 \mathrm{~b}$ & $47.8 \mathrm{~b}$ & $0.4 \mathrm{~b}$ & $9.9 \mathrm{ab}$ & $-0.96 \mathrm{a}$ \\
Significance $^{\mathrm{z}}$ & $\mathrm{L}^{*}$ & $\mathrm{~L}^{*}$ & $\mathrm{~L}^{*}$ & $\mathrm{~L}^{*}$ & $\mathrm{~L}^{* *}$ \\
\hline
\end{tabular}

${ }_{\mathrm{z}} \mathrm{L}=$ linear; NS, $*, * *$ Nonsignificant or significant at $P \leq 0.05$ or 0.01 , respectively.

Community for lettuce grown under cover irrespective of the season (European Commission, 2011). The linear reduction in nitrate content with increasing $\mathrm{NaCl}$ concentration in the irrigation water is associated to the antagonism effect between nitrate and chloride. Rubinigg et al. (2003) and Borgognone et al. (2016) showed that in the presence of high chloride levels, root-to-shoot translocation of nitrate could be reduced at the site of entrance into xylem parenchyma cells through competition for the same channel.

High level of $\mathrm{NaCl}$ in irrigation water or the growing medium hampers plant physiological processes such as photosynthesis as well as water relations (Munns, 2005). This was the case in the current experiment because the significant differences between the water irrigation treatments on the agronomical traits were also observed at the physiological level. Net $\mathrm{CO}_{2}$ assimilation rate declined with increasing the $\mathrm{NaCl}$ concentration in the irrigation water. The reduction in photosynthetic capacity in response to salinity could be correlated to the accumulation of toxic elements $\mathrm{Na}$ or $\mathrm{Cl}$ in leaf tissues as observed previously in several vegetable crops (Colla et al., 2012; Martinez-Ballesta et al., 2004; Rouphael et al., 2012c). Furthermore, the inhibition of photosynthesis induced premature senescence, inhibition of chlorophylls and carotenoids biosynthesis as well as compromising the translocation of assimilates to phostosynthetic sinks leading to a significant reduction in plant growth (Colla et al., 2012; Stepien and Klobus, 2006).

It is well established that the salt-induced limitation of photosynthesis could be due to stomatal or nonstomatal factors, the latter are not fully elucidated (Debez et al., 2008). The concomitant reduction in $\mathrm{CO}_{2}$ assimilation, which was linearly correlated to $g_{\mathrm{s}}\left(R^{2}=0.82\right.$, data not shown) indicate the occurrence of stomatal limitation of photosynthesis (Mahmoudi et al., 2011; Neocleous et al., 2014; Parida and Das, 2005). In fact the saltstressed lettuce plants especially at 3.6 and $7.2 \mathrm{dS} \cdot \mathrm{m}^{-1}$ reacted by the closure of stomata to minimize water loss by $\mathrm{E}$, which was reduced by $50 \%$ in comparison with the 0.7 , 0.9 , and $1.8 \mathrm{dS} \cdot \mathrm{m}^{-1}$ treatments. The intrinsic water use efficiency $\left(\mathrm{A} / g_{\mathrm{s}}\right)$ remained quite high (ranging 0.118-0.092) and did not strongly decreased under most stressful conditions, therefore, indicating the non-stomatal components of photosynthetic limitations had not developed yet (Flexas et al., 2004). Moreover, the $\mathrm{WUE}_{\mathrm{i}}$ calculated by the ratio $\mathrm{A}$ to $\mathrm{E}$, increased at $3.6 \mathrm{dS} \cdot \mathrm{m}^{-1}$, indicating that there were water restrictions rather than inhibition of net photosynthesis (Flexas et al., 2004). The concept of high WUE is an important aspect for salt tolerance as high WUE may suppress the uptake and translocation of toxic ions and mitigate water deficiency induced by salt stress conditions (Karaba et al., 2007; Moya et al., 1999; Neocleous et al., 2014).

Similarly to leaf gas exchange measurements, salinity stress caused a marked decrease in LWP (more negative), especially at 3.6 and $7.2 \mathrm{dS} \cdot \mathrm{m}^{-1}$. The salt-induced reduction in LWP has been observed earlier on several vegetable crops (Shahbaz et al., 2012; Singh et al., 2010; Yousif et al., 2010). The decrease in LWP under severe salt stress conditions has been attributed to several mechanisms including the excessive accumulation of toxic ions (e.g., $\mathrm{Na}^{+}$and $\mathrm{Cl}^{-}$) in the shoot tissues and also to decreased accessibility of water to the root system because of the reduction of water conductivity, which leads to decreased evapotranspiration and crop productivity (Maksimovic and Ilin, 2012; Sohan et al., 1999).

\section{Conclusion}

The present study reveals that plant growth parameters and marketable fresh yield of greenhouse lettuce decreased linearly with increasing salinity of irrigation water especially at 3.6 and $7.2 \mathrm{dS} \cdot \mathrm{m}^{-1}$. The reduction in yield could be partly compensated by a decrease in nitrate content of salttreated lettuce. Our results also demonstrated that the reduction of crop productivity under saline conditions $\left(>1.8 \mathrm{dS} \cdot \mathrm{m}^{-1}\right)$ depends on the reduced uptake of water as well as on the decrease of net $\mathrm{CO}_{2}$ assimilation.

\section{Literature Cited}

Amr, A. and N. Hadidi. 2001. Effect of cultivar and harvest data on nitrate $\left(\mathrm{NO}_{3}\right)$ and nitrite $\left(\mathrm{NO}_{2}\right)$ content of selected vegetables gown under open field and greenhouse conditions in Jordan. J. Food Compos. Anal. 14:59-67.

Andriolo, J.L., G.L. da Luz, M.H. Witter, R.S. Godori, G.T. Barros, and O.G. Bortolotto. 2005. Growth and yield of lettuce plants under salinity. Hort. Bras. 23:931-934. 
Borgognone, D., Y. Rouphael, M. Cardarelli, L. Lucini, and G. Colla. 2016. Changes in biomass, mineral composition, and quality of cardoon in response to $\mathrm{NO}_{3}^{-}: \mathrm{Cl}^{-}$ratio and nitrate deprivation from the nutrient solution. Front. Plant Sci. 7:978.

Colla, G., Y. Rouphael, M. Cardarelli, D. Massa, A. Salerno, and E. Rea. 2006a. Yield, fruit quality and mineral composition of grafted melon plants grown under saline conditions. J. Hort. Sci. Biotechnol. 81:146-152.

Colla, G., Y. Rouphael, M. Cardarelli, and E. Rea. 2006b. Effect of salinity on yield, fruit quality, leaf gas exchange, and mineral composition of grafted watermelon plants. HortScience 41:622-627.

Colla, G., Y. Rouphael, M. Cardarelli, E. Svecova, E. Rea, and L. Lucini. 2013a. Effects of saline stress on mineral composition, phenolics acids and flavonoids in leaves of artichoke and cardoon genotypes grown in floating system. J. Sci. Food Agr. 93:1119-1127.

Colla, G., Y. Rouphael, M. Cardarelli, M. Tullio, C.M. Rivera, and E. Rea. 2008. Alleviation of salt stress by arbuscular mycorrhizal in zucchini plants grown at low and high phosphorus concentration. Biol. Fertil. Soils 44:501-509.

Colla, G., Y. Rouphael, C. Fallovo, M. Cardarelli, and A. Graifenberg. 2006c. Use of Salsola sodaas a companion plant to improve greenhouse pepper (Capsicum annuum) under saline conditions. New Zeal J. Hort. Sci. 34:283-290.

Colla, G., Y. Rouphael, R. Jawad, P. Kumar, E. Rea, and M. Cardarelli. 2013b. The effectiveness of grafting to improve $\mathrm{NaCl}$ and $\mathrm{CaCl}_{2}$ tolerance in cucumber. Scientia Hort. 164:380-391.

Colla, G., Y. Rouphael, E. Rea, and M. Cardarelli. 2012. Grafting cucumber plants enhance tolerance to sodium chloride and sulfate salinization. Scientia Hort. 135:177-185.

Colonna, E., Y. Rouphael, G. Barbieri, and S. De Pascale. 2016. Nutritional quality of ten leafy vegetables harvested at two light intensities. Food Chem. 199:702-710.

Debez, A., H.W. Koyro, C. Grignon, C. Abdelly, and B. Huchzermeyer. 2008. Relationship between the photosynthetic activity and the performance of Cakile maritime after long-term salt treatment. Physiol. Plant. 133:373-385.

EFSA. 2008. Opinion of the scientific panel on contaminants in the food chain on a request from the European commission to perform a scientific risk assessment on nitrate in vegetables. EFSA J. 689:1-79.

European Commission. 2011. Commission regulations (EU) No 1258/2011 of 2 Dec. 2011 amending regulation (EC) No 1881/2006 as regards maximum levels for nitrates in foodstuffs (Text with EEA relevance). Off. J. Eur. Union L320:15-17.

FAO. 2014. The state of food and agriculture. 1 Sept. 2017. <http://www.fao.org/3/a-i4040e.pdf $>$.

Flexas, J., J. Bota, F. Loreto, G. Cornic, and T.D. Sharkey. 2004. Diffusive and metabolic limitations to photosynthesis under drought and salinity in C3 plants. Plant Biol. 6:269-279.

Fogliano, V., V. Verde, G. Randazzo, and A. Ritieni. 1999. Method for measuring antioxidant activity and its application to monitoring the antioxidant capacity of wines. J. Agr. Food Chem. 47:1035-1040.

Garrido, Y., J.A. Tudela, A. Marín, T. Mestre, V. Martínez, and M.I. Gil. 2014. Physiological, phytochemical and structural changes of multileaf lettuce caused by salt stress. J. Sci. Food Agr. 94:1592-1599.

Gomez, K.A. and A.A. Gomez. 1983. Comparison between treatment means, p. 187-240. In: K.A.
Gomez and A.A. Gomez (eds.). Statistical procedures for agricultural research. 2nd ed. John Wiley \& Sons, New York, NY.

Grattan, S.R. and C.M. Grieve. 1999. Salinitymineral nutrient relations in horticultural crops. Scientia Hort. 78:127-157.

Kampfenkel, K., M.V. Montagu, and D. Inzè. 1995. Extraction and determination of ascorbate and dehydroascorbate from plant tissue. Annu. Rev. Biochem. 225:165-167.

Karaba, A., S. Dixit, R. Greco, A. Aharoni, K.R. Trijatmiko, N. Marsch-Martinez, A. Krishnan, K.N. Nataraja, M. Udayakumar, and A. Pereira. 2007. Improvement of water use efficiency in rice by expression of HARDY, an Arabidopsis drought and salt tolerance gene. Proc. Natl. Acad. Sci. USA 104:15270-15275.

Kim, H., H. Jeong, J. Jeon, and S. Bae. 2016a Effects of irrigation with saline water on crop growth and yield in greenhouse cultivation. Water 8:127.

Kim, M.J., Y. Moon, J.C. Tou, B. Mou, and N.L. Waterland. 2016b. Nutritional value, bioactive compounds and health benefits of lettuce ( $\mathrm{Lac}$ tuca sativa L.). J. Food Comp. Analys. 49:19-34.

Kyriacou, M.C. and Y. Rouphael. 2017. Towards a new definition of quality for fresh fruits and vegetables. Scientia Hort. doi: https://doi.org/ 10.1016/j.scienta.2017.09.046.

Lucini, L., Y. Rouphael, M. Cardarelli, R. Canaguier, P. Kumar, and G. Colla. 2015. The effect of a plantderived protein hydrolysate on metabolic profiling and crop performance of lettuce grown under saline conditions. Scientia Hort. 182:124-133.

Mahmoudi, H., R. Kaddour, J. Huang, B. Nasri, B Olfa, S. M'Rah, A. Hannoufa, M. Lachaal, and Z. Ouerghi. 2011. Varied tolerance to $\mathrm{NaCl}$ salinity is related to biochemical changes in two contrasting lettuce genotypes. Acta Physiol. Plant. 33:1613-1622.

Maksimovic, I. and Ž. Ilin. 2012. Effects of salinity on vegetable growth and nutrients uptake, irrigation systems and practices in challenging environments. In: T.S. Lee (ed.). ISBN: 978953-510420-9, InTech. 2 Sept. 2017. <http:// www.intechopen.com/books/irrigation-systemsand-practices-inchallenging-environments/effectsof-salinity-on-vegetable-growth-and-nutrientsuptake>.

Martinez-Ballesta, M.C., V. Martinez, and C. Carvajal. 2004. Osmotic adjustment, water relations and gas exchange in pepper plants grown under $\mathrm{NaCl}$ or $\mathrm{KCl}$. Environ. Expt. Bot. 52:161-174.

Mass, E.V. and S.R. Grattan. 1999. Crop yields as affected by salinity, p. 55-108. In: R.W Skaggs and J. van Schilfgaarde (eds.). Agricultural Drainage. American Society of Agronomy, Crops Science Society of America, Soil Science Society of America, Madison, WI.

Mass, E.V. and G.J. Hoffman. 1977. Crop salttolerance - current assessment. J. Irrig. Drain. Div. 103:115-134.

Mori, M., M. Amato, I. Di Mola, R. Caputo, F. Quaglietta Chiarandà, and T. Di Tommaso. 2008. Productive behaviour of "cherry"-type tomato irrigated with saline water in relation to nitrogen fertilization. Eur. J. Agron. 29:135-143.

Mori, M., I. Di Mola, and F. Quaglietta Chiarandà. 2011. Salt stress and transplant time in snap bean: Growth and productive behaviour. Intl. J. Plant Prod. 5:49-64.

Moya, J.L., E. Primo-Millo, and M. Talon. 1999. Morphological factors determining salt tolerance in citrus seedlings: The shoot to root ratio modulates passive root uptake of chloride ions and their accumulation in leaves. Plant Cell Environ. 22:1425-1433.
Munns, R. 2002. Comparative physiology of salt and water stress. Plant Cell Environ. 25:239-250.

Munns, R. 2005. Genes and salt tolerance: Bringing them together. New Phytol. 167:645-663.

Neocleous, D., A. Koukounaras, A.S. Siomos, and M. Vasilakakis. 2014. Changes in photosynthesis, yield, and quality of baby lettuce under salinity stress. J. Agr. Sci. Technol. 16:13351343.

Ntatsi, G., K.A. Aliferis, Y. Rouphael, F. Napolitano, K. Makris, G. Kalala, G. Katopodis, and D. Savvas. 2017. Salinity source alters mineral composition and metabolism of Cichorium spinosum. Environ. Expt. Bot. 141:113-123.

Orsini, F., A. Maggio, Y. Rouphael, and S. De Pascale. 2016. "Physiological quality" of organically grown vegetables. Scientia Hort. 208:131-139.

Parida, K.A. and B.A. Das. 2005. Salt tolerance and salinity effects on plants: A eeview. Ecotoxicol. Environ. Saf. 60:324-349.

Pasternak, D., Y. De Malach, I. Borovic, M. Shram, and C. Aviram. 1986. Irrigation with brackish water under desert conditions. IV. Salt tolerance studies with lettuce (Lactuca sativa L.). Agr. Water Mgt. 11:303-311.

Pellegrini, N., R. Re, M. Yang, and C. Rice-Evans. 1999. Screening of dietary carotenoids and carotenoid-rich fruit extracts for antioxidant activities applying 2,2' azinobis(3-ethylenebenzothiazoline-6- sulfonic acid radical cation decolorization assay. Methods Enzymol. 299:379-384.

Rouphael, Y., M. Cardarelli, A. Bassal, C. Leonardi, F. Giuffrida, and G. Colla. 2012a. Vegetable quality as affected by genetic, agronomic and environmental factors. J. Food Agr. Environ. 10:680-688.

Rouphael, Y., M. Cardarelli, P. Bonini, and G. Colla. 2017a. Synergistic action of a microbialbased biostimulant and a plant derived-protein hydrolysate enhances lettuce tolerance to alkalinity and salinity. Front. Plant Sci. 8:131.

Rouphael, Y., M. Cardarelli, L. Lucini, E. Rea, and G. Colla. 2012b. Nutrient solution concentration affects growth, mineral composition, phenolic acids and flavonoids in leaves of artichoke and cardoon. HortScience 47:1424-1429.

Rouphael, Y., M. Cardarelli, E. Rea, A. Battistelli, and G. Colla. 2006. Comparison of the subirrigation and drip-irrigation systems for greenhouse zucchini squash production using saline and non-saline nutrient solution. Agr. Water Mgt. 82:99-117.

Rouphael, Y., M. Cardarelli, E. Rea, and G. Colla. 2012c. Improving melon and cucumber photosynthetic activity, mineral composition, and growth performance under salinity stress by grafting onto Cucurbita hybrid rootstocks. Photosynthetica 50:180-188.

Rouphael, Y., G. Colla, L. Bernardo, D. Kane, M. Trevisan, and L. Lucini. 2016. Zinc excess triggered polyamines accumulation in lettuce root metabolome, as compared to osmotic stress under high salinity. Front. Plant Sci. 7:842.

Rouphael, Y., V. De Micco, C. Arena, G. Raimondi, G. Colla, and S. De Pascale. 2017b. Effect of Ecklonia maxima seaweed extract on yield, mineral composition, gas exchange and leaf anatomy of zucchini squash grown under saline conditions. J. Appl. Phycol. 29:459-470.

Rouphael, Y., M. Kyriacou, P. Vitaglione, M. Giordano, A. Pannico, A. Colantuono, and S. De Pascale. 2017c. Genotypic variation in nutritional and antioxidant profile among iceberg lettuce cultivars. Acta Sci. Pol. Hortorum Cultus 16:37-45. 
Rubinigg, M., F. Posthumus, M. Ferschke, J. Theo, M. Elzenga, and I. Stulen. 2003. Effects of $\mathrm{NaCl}$ salinity on $15 \mathrm{~N}$-nitrate fluxes and specific root length in the halophyte Plantago maritima L. Plant Soil 250:201-213.

Sah, R.N. 1994. Nitrate-nitrogen determination: A critical review. Commun. Soil Sci. Plant Anal. 25:2841-2869.

Savvas, D., A. Savva, G. Ntatsi, A. Ropokis, I. Karapanos, A. Krumbein, and C. Olympios. 2011. Effects of three commercial rootstocks on mineral nutrition, fruit yield, and quality of salinized tomato. J. Plant Nutr. Soil Sci. 174:154-162.

Scholander, P.F., H.T. Hammel, E.D. Bradstreet, and E.A. Hemmingsen. 1965. Sap pressure in vascular plants. Science 148:339-346.
Shahbaz, M., M. Ashraf, F. Al-Qurainy, and P.J.C. Harris. 2012. Salt tolerance in selected vegetable crops. Crit. Rev. Plant Sci. 31:303-320.

Singh, P., N. Singh, K.D. Sharma, and M.S. Kuhad 2010. Plant water relations and osmotic adjustment in Brassica species under salinity stress. J. Amer. Sci. 6:1-4.

Sohan, D., R. Jasoni, and J. Zajicek. 1999. Plantwater relations of $\mathrm{NaCl}$ and calcium-treated sunflower plants. Environ. Expt. Bot. 42:105-111.

Stepien, P. and G. Klobus. 2006. Water relations and photosynthesis in Cucumis sativus L. leaves under salt stress. Biol. Plant. 50:610-616.

Subbarao, V.K. 1998. Progress toward integrated management of lettuce drop. Plant Dis. $82: 1068-1078$.
Turner, N.C. and M.J. Long. 1980. Errors arising from rapid water loss in the measurement of leaf water potenti al by the pressure chamber technique. Funct. Plant Biol. 7:527-537.

Unlükara, A., B. Cemek, S. Karaman, and S. Ersahin. 2008. Response of lettuce (Lactuca sativa var. Crispa) to salinity of irrigation water. N. Z. J. Crop Hort. Sci. 36:263-271.

Yousif, B.S., N.T. Nguyen, Y. Fukuda, H. Hakata, Y. Okamoto, Y. Masaoka, and H. Saneoka. 2010. Effects of salinity on growth, mineral composition, photosynthesis and water relations of two vegetables crops; New Zealand spinach (Tetragonia tetragonioides) and water spinach (Ipomoea aquatica). Intl. J. Agr. Biol. 12:211-216. 